\title{
PEDAGOGICAL PROCEDURES FOR THE FORMATION OF INTELLECTUAL AND WILL RESPONSIBILITIES IN THE DEVELOPMENT OF ANTIFRUSTRATION SKILLS IN FUTURE SCIENCE TEACHERS
}

\author{
Dilora Aliyevna Jarqinova
}

Lecturer Fergana Public Health Institute of Medicine Biophysics and Information Technology, Uzbekistan

\section{ABSTRACT}

The article provides insights into the effectiveness of the formation of intellectual and volitional traits in the development of antifrustration skills in future science teachers. An empirical analysis of the author's research is also presented.

KEYWORDS:- Stress, depression, despair, antifrustration, frustration, individual-psychological, tolerance.

\section{INTRODUCTION}

Today, scientists believe that stress, depression, and despair have become the "disease of the century." Despair and stress not only affect one's life, but also the mental and physical health of one's family and loved ones. The development of antifrustration skills in frustrating [1] situations is a topical pedagogical problem, especially in the training of future science teachers in the higher education system. According to the WHO, 65\% of all illnesses [3] are caused by stress. According to the American Psychological Association, "stress ... is a major threat to student health. Also, if young people do not learn healthy ways to manage stress today, it can have a serious impact on their health. "[4] These scientific findings have led to pedagogical conclusions that a student's stressful, frustrating state of frustration can have a serious negative impact not only on his or her learning but also on his or her creative development. Evidence suggests that research has been conducted to develop the antifrustration skills of educators in situations of frustration [5] during the training process. However, little research has been done on the development of antifrustration skills for future science teachers. In this study, we developed scientific conclusions on the development of antifrustration skills of future science teachers through person-centered education.

\section{Materials AND METHODS}

The study of the problem of developing 
CURRENT RESEARCH JOURNAL OF PEDAGOGICS 2(6): 27-31, June 2021

DOI: https://doi.org/10.37547/pedagogics-crjp-02-06-07

ISSN 2767-3278

(C)2021 Master Journals

\section{Crossref do) 8 Google}

Accepted 11 thJune, 2021 \& Published 16 ${ }^{\text {th }}$ June, 2021

antifrustration properties in students is reflected in the works of such authors as S. Rosensweig, N.D. Levitov, F.E. Vasilyuk, I.P. Ilin, Yu.N. Kulyutkin, R.P. Milrud, R.I. Khmelyuk, Z.N. Kurlyand, N.A. These authors did not consider frustration tolerance as a separate subject in their work, they addressed the problem of stress tolerance in their work on stress, frustration, frustration, and the manifestation of individual behavior in the process.

\section{ReSUlTS AND DISCUSSION}

The development of antifrustration skills through education in future science teachers is an important pedagogical process in the formation of pedagogical professionals. Psychologists are still interested in the question of what pedagogical factors are important in the development of antifrustration skills in future science teachers. The continuous formation of frustrated character in students has to be assessed through a series of relationship systems based on personal position. This can be reconciled with the idea that, firstly, the development of character traits in certain places should take a certain form, and secondly, it should take place as a frustrating trait of the person. However, in the pedagogical process, it is expedient to study the teacher's selfmanagement in certain situations, which in many ways determines the frustrating features of the student's character and, in proportion to it, determines his own behavior. We found it necessary to study the effectiveness of the formation of intellectual and volitional qualities in the development of antifrustration skills in future teachers of science in the pedagogical process. Here are some examples of psychological qualitative analysis of this problem. There are a number of factors to consider when discussing the formation of antifrustration characteristics at all stages of the lifelong learning process. However, as the object of our research is to analyze the factors that develop antifrustration skills in future science teachers, we need to take into account some important aspects of their study. First, antifrustration skills in future science teachers will be less formed than in social science students because the requirements for studying in the exact sciences are that they only need to study the exact sciences, only the importance of the specialty sciences emphasizes. As a result, they are more likely to experience frustration. Second, future science teachers are inexperienced in dealing with frustrating situations for schoolchildren, even in their teaching activities, due to a lack of antifrustration skills and experience. As a result, the high incidence of this condition leads to a slowdown in education in the secondary education system. The same is true in the context of our study of the formation of the volitional and intellectual qualities of a frustrated character as a problem for future science teachers. This is because if future science teachers do not have the opportunity to develop professional skills and competencies to deal with the initial pedagogical and frustrating situations during their education, then they will be able to use the educational process as a personal example. He himself is questioned by the society in terms of finding his place. Given these similar circumstances, we will refer to the analysis of the results of the initial investigative study devoted to the study of the volitional and intellectual characteristics of the frustrated character in students. In our study, we found it necessary to use a combination of methods to determine the level of formation of volitional qualities and intellectual characteristics of a number of individuals, as there is no integrated set of methods for studying the frustrating will and intellectual characteristics of certain science teachers. Thus 
CURRENT RESEARCH JOURNAL OF PEDAGOGICS 2(6): 27-31, June 2021

DOI: https://doi.org/10.37547/pedagogics-crjp-02-06-07

ISSN 2767-3278

(C)2021 Master Journals

\section{Crossref do) 8 Google}

Accepted 11 thJune, 2021 \& Published 16 ${ }^{\text {th }}$ June, 2021

N.N. From Obozov's questionnaires "Evaluation of willpower", "Tolerance", "Perseverance" and "Diligence" in students (Ye.P. Ilin and EK Feshenko), as well as the study of intellectual qualities A.Alekseyev and L.Gromova's test "Individual thinking style", a number of other similar methods. In our study, specific science teachers focused on the mechanisms of formation of volitional and intellectual characteristics of the frustrated character, as well as the emotional response to anxiety caused by various specific conditions, objective and subjective influences that affect the process of their formation. we planned to study in sync with the circumstances. We will focus on quantitative analysis of the empirical results obtained during the experiment. we will look at the indicators of the formation of the volitional characteristics of the frustrating character of specific science teachers in the general case and in the individual stages. We have been able to explore in them the general willpower and the special patience, perseverance and diligence in the formation of the willpower of the character. Teachers of science can mobilize the general willpower to solve problems in the daily life and education of students in higher education institutions in the study of the level of formation of willpower in a frustrating nature, as well as their self-control in the acquisition of knowledge. analysis based on knowledge, perseverance, perseverance, and maturity of diligence. According to the criteria of the methodology, when we analyze the state of the general willpower of students in the stages of education - the willpower in the first stage 14.74, in the second stage - 19.34, in the third stage - 20, 94 indicators. reflects that maturity depends not only on age, but also on their individual-psychological characteristics. From this, it can be seen that the importance of general willpower in the formation of the volitional characteristics of a frustrated character in students can serve as a basis for the formation of the necessary qualities in them? the question arises. We can conclude from the results of our study that the higher the willpower, the more positive it is in the formation of character traits. However, although there are differences in the results of the experience of specific science teachers in the learning stages, but according to the criteria for assessing the methodological indicators, their overall willpower is weak for students of level 1, and in stages 2-3 On average, Level 4 allows high school graduates to conclude that it is high. It is worthwhile for future science teachers to refer to the results of the examination of other volitional traits of character, in addition to the frustrating general willpower. When the characteristics of patience, perseverance and diligence of teachers of specific sciences were studied, patience in all three stages of education [1] showed an average level of endurance (Level 1 - 10.80, Level 2 - 11.80, and Level 3 - 12.51, 4 - stage 13.51). The results show that future science teachers are not always able to show high resilience in the face of difficulties in life and problems with the acquisition of knowledge in the educational process. In fact, the higher the level of perseverance, the higher the level of perseverance in achieving the set goals and the more diligent in carrying out the plans. Even the confirmation of this idea can be seen in the results obtained by future science teachers on the characteristics of perseverance and diligence. Their persistence: weak in stage 1 - 10.82, stage $2-11.20$ and stage $3-12.62$, stage $4-13.70$ Future science teachers showed an average score.

\section{Conclusion}

- Our conclusions and analysis show that the following scientific basis can be given for the assessment of the anti-frustration will 
and intellectual nature of future science teachers through person-centered education:

- Elements of the structure of the development of antifrustration skills of future teachers of science through personcentered education (logic, innovation and self-management) by ensuring their interaction on the basis of the integration of diagnostic criteria and pedagogical tools improved content;

- The mechanism of development of competencies such as mobility, reflexivity, integration in the areas of theoretical, practical, research training based on the classification of the stages of development of antifrustration skills of future science teachers through person-centered education has been improved;

- Deepening the process of developing antifrustration skills of future science teachers through person-centered education on the set of parameters and quality indicators of competence requirements and their exit from the fruiting situation on the basis of optimization of teaching aids improved methodology;

- Determinants that affect students' resilience to difficult life situations and its low or high manifestations, in particular, adequate or inadequate self-esteem, increased or decreased self-confidence, the degree of overcoming frustrating barriers, frustration tolerance mutually positive correlations between high and low levels were determined on the basis of empirical results;

\section{ReFERENCES}

1. "Frustration is a disorderly psychological state of consciousness and activity of a person, which is an insurmountable and unfounded (or such perceptions and experiences by the subject) objectively in the way that a person is desperate to achieve his goal. 'squeeze' .. Psychological dictionary. // Pod red. A.V.Petrovskogo and M.G.Yarashevskogo. - M., 1993.

2. Voluntarism (Latin - voluntas - will) - a doctrine based on the idea of the primacy of the human will in philosophy, pedagogy and psychology, Pedagogy. Encyclopedia. Volume 1 - Tashkent: "National Encyclopedia of Uzbekistan" State Scientific Publishing House, 2015. -B. 201

3. World Health Organization www.who.into - Xalqaro sog'liqni saqlash tashkilotining rasmiy sayti (murojaat holati 10.10.2019)

4. American Psychological Association. www.unicef.org

5. 4. Competent Learning Technologies is a learning process based on the principle of gender equality and non-violence, a technology aimed at building group selforganization skills through direct experience. . Pedagogy. Encyclopedia. Volume 1 - Tashkent: "National Encyclopedia of Uzbekistan" State Scientific Publishing House, 2015. -B. 184.

6. Сиддиков, И. Б. (2019). Государственная политика в отношении молодежи в Узбекистане: национальный опыт и реальная необходимость международных инициатив. In Условия социально-экономического развития общества: история и современность (рр. 
CURRENT RESEARCH JOURNAL OF PEDAGOGICS 2(6): 27-31, June 2021

DOI: https://doi.org/10.37547/pedagogics-crjp-02-06-07

ISSN 2767-3278

(C)2021 Master Journals

Crossref dof 81 Google

Accepted 11 $1^{\text {th }}$ June, 2021 \& Published $16^{\text {th }}$ June, 2021

38-43).

7. Bakhromovich, S. I. (2020). The impact of managerial professional development on the effectiveness of Higher Education institution management. Academicia: an international multidisciplinary research journal, 10(12), 1014-1020. 